\title{
What Are We Talking About?
}

\begin{abstract}
In this chapter, we present a few definitions of post-truth and explain why the human capacity for lying and influencing others with false information, which is not new in human history, has given birth to alarming new dangers in recent years. We also set forth our path for describing the history and theoretical claims underlying the phenomenon of posttruth, accounting briefly for the social, political, and economic changes posed by individualization, bureaucratization, and globalization issues that will not be addressed in the remainder of the book.
\end{abstract}

Keywords Deceptive communication • Human nature • Individualization • Bureaucratization • Globalization

The concepts of 'post-truth' and 'fake news' have for a number of years occupied centre stage in the arenas of communication and international politics. The Oxford English Dictionary (OED) selected the adjective 'post-truth' as its word of the year in 2016, offering this definition: "Relating to or denoting circumstances in which objective facts are less influential in shaping public opinion than appeals to emotion and personal belief."

Fake news is the principal manifestation of the post-truth phenomenon. The Cambridge Dictionary defines 'fake news' as "false stories that appear to be news, spread on the internet or using other media, usually created to

(C) The Author(s) 2020

G. Maddalena, G. Gili, The History and Theory of Post-Truth

Communication, https://doi.org/10.1007/978-3-030-41460-3_1 
influence political views or as a joke"; a similar definition of the term in the Collins Dictionary (which declared 'fake news' its word of the year for 2017) holds that it is "false, often sensational, information disseminated under the guise of news reporting." The committee of the Australian Macquarie Dictionary, which chose fake news as its 2016 word of the year, described it as "one of the big issues of the year around the world," capturing "an interesting evolution in the creation of deceptive content as a way of herding people in a specific direction."

While the success of the expressions post-truth and fake news is recent, ${ }^{1}$ the concepts they embody are far from new. The possibility of lying and influencing others with false information, exploiting their emotions and personal beliefs, is as old as communication itself because it is inherent in human nature. Gregory Bateson noted that animals communicate with a simplicity and innocence that humans have lost, noting that "man's behavior is corrupted by deceit-even self-deceit-by purpose, and by selfconsciousness" (Bateson 1972, p. 137). The ability to lie is connected to mankind's superior cognitive capacity and presupposes a high level of awareness and reflection. These factors render human communication much richer and more versatile than animal communication, but at the same time more opaque, ambiguous, and subject to abuse and deception.

Two of Western civilization's foundational stories attest to the fact that deceptive communication has always existed. After committing the 'original sin' described in the Bible, Adam and Eve clumsily try to hide their transgression from God (Gen.: III, 1-13); shortly thereafter, Cain attempts to deceive his creator by claiming that he is innocent of the murder of his brother Abel (Gen.: IV, 1-10). Homer's epics, pillars of the other cradle of Western society, Greece, describe the deception by which the Achaean army, inspired by Ulysses, breaches the walls of Troy (Odyssey: VIII, 500-520); today, the expression 'Trojan horse' has found its way into the language generally as anything that attempts to deceptively subvert from within; one specific use of the expression in the area of computer technology refers to a type of malware that hides its destructive purposes within an apparently useful or innocuous programme.

It should therefore not be surprising that every era has been rife with fake news. One example is the forged Donation of Constantine, an apocryphal medieval text used to legitimize the temporal power of the church, which was exposed as a fake only many centuries later by the humanist Lorenzo Valla after he discovered historical and linguistic inconsistencies within the document. Others include the campaign of disparagement 
aimed at the French Queen Marie Antoinette, which doomed her historical reputation and sealed her tragic fate (Darnton 2017); the exaggerated Ems Dispatch, used by Bismarck to trigger the Franco-Prussian War in 1870; and the documents ingeniously forged by officers of the French general staff to support the accusations of treason levelled against the Alsatian Jewish captain Alfred Dreyfus, which, even after their counterfeit origin was revealed, were cited by the far-right intellectual Charles Maurras as a patriotic forgery (Margalit 2017). Some pieces of fake news have identifiable and acknowledged authors, while others are spread through less public means that make them difficult to ascribe to a verifiable source, as was the case with the 'Great Fear' that spread through several rural areas of France in the summer of 1789 as the result of unchecked rumours of an aristocratic conspiracy, an imminent foreign invasion, and brigand raids killing farmers and destroying crops. These rumours induced the peasants to arm themselves and rise up against the aristocracy (Lefebvre 1932). In other cases, the invisible hand behind the diffusion of fake news has been unmasked only after many years, as happened in the early 1990s when Russian intelligence executive Yevgeny Primakov conceded that KGB instigated the myth that HIV had been created in a laboratory on the orders of the US government (Riva 2018).

If, therefore, the concepts behind the expressions post-truth and fake news have a long history, what is behind the current rise in interest and alarm that has led to the paradoxical 'success' of these two new expressions? Why has there been such an enormous recent increase in the diffusion of fake news that distorts truth, exacerbates divisions, and threatens people's trust in democratic institutions, politics, and science?

We will first attempt to document the ways in which the notion of posttruth is currently manifesting itself and describe the vast array of phenomena that can be referred to as fake news. We will then attempt to trace some of the principal roots of the concept of post-truth, with the goal of understanding how it came by its present meaning and the extent of the problems it poses. The concept of post-truth is in fact the ripe and poisonous fruit of a tree fertilized and watered by many gardeners: some with good intentions, some with bad intentions, and others without a full understanding of the consequences of their actions. We are aware that not every relevant field or discipline that contributed to the creation of the phenomenon of fake news can be adequately explored here, but we believe that what we can explore here will allow us to take significant steps towards 
clarifying the meaning and current relevance of both post-truth and fake news.

The use of deception and manipulation in the political and commercial world underwent a rapid acceleration in the twentieth century as a result of three related and mutually reinforcing processes. The first was the refinement and increased diffusion of mass media: newspapers and magazines, radio, cinema, and television. At the same time, for economic and political reasons, these tools became increasingly concentrated in the hands of the state or of massive political and corporate organizations. As early as the 1940s, the sociologist Karl Mannheim described the outline of the problem: on the one hand, mass media had been an essential factor in the "fundamental democratization of society," while on the other it created exceptionally dangerous concentrations of power with the potential to influence and control populations, a potential that was then being tragically realized by totalitarian regimes (Mannheim 1940).

Second, psychology and sociology continued to develop their understanding of human intentions, motivations, and behaviour throughout the course of the twentieth century. The early works of Le Bon and Freud gave birth to a field of study that is now known as the psychosociology of collective and social phenomena, which investigated these processes in depth. Its teachings were put to use for the purposes of political indoctrination and to satisfy the needs of consumer society, and were subjected to critical analysis, initially by the various strains of the theory of mass society (Bramson 1961; Giner 1976; Gili 2001).

The third essential, and perhaps least investigated, cultural process of the twentieth century that led to the development of post-truth and all that it refers to involves a transformation of the concepts of 'truth' and 'reality'; previously, although these concepts had undergone change, they had always been understood to have a relationship with each other that provided a barrier against manipulative actions and projects. In the twentieth century, these two concepts were subjected to radical scrutiny, for reasons we will discuss below, in the fields of philosophy, social science, and media studies.

The first twenty years of the twenty-first century, as noted by the Macquarie Dictionary, have seen "an interesting evolution in the creation of deceptive content." This evolution is closely connected to globalization and digital revolution because these intertwined processes have strengthened lying and manipulating in three main directions: a more extensive spreading of lies and more people being deceived, a deeper penetration 
into public opinion thanks to social media, and a greater speed with which fake news can circulate within the system of communication. It is now far easier to quickly spread fake news while hiding its origins in such a way as to make it very difficult to verify or rebut its truthfulness. Even in cases when fake news is quickly debunked, it has usually already been disseminated around the world several times and produced its damaging effects.

In this book, we consciously chose an approach that emphasizes culture and communication. The reader should not forget, however, that certain structural processes operating in contemporary societies related to the social, economic, and political dimensions of these societies have also contributed to the present crisis relating to truth and reality. These structural processes affect people's use of reason, that is, their capacity to judge reality, causing them to judge it by more emotional and idiosyncratic means (following the definition of post-truth set forth above). Before describing below the path of our cultural and communicative focus in Chaps. 2, 3, 4, and 5 , we briefly describe three of these structural processes: individualization, bureaucratization, and globalization.

Individualization is the process by which people lose, or free themselves from, the web of social relationships that once supported them and bound them together. From a macro-social standpoint, individualization has created a progressively more atomistic society. This process has gained momentum over the last two centuries, and its present-day fruit can be seen in the fact that it has transformed everyone's personal, and even intimate, life. In his book Risk Society, the sociologist Ulrich Beck observes that "the basic figure of fully developed modernity is the single person" (Beck 1992, p. 122). Accordingly, society is now "the fully mobile society of singles" (ibid.). Beck argues that this society of singles is the direction towards which we are all moving and that this course is irreversible. He believes that this society is the structural outcome of modernity and the attendant developments in the job market:

The form of existence of the single person is not a deviant case along the path of modernity. It is the archetype of the fully developed labor market society. The negation of social ties that takes effect in the logic of the market begins in its most advanced stage to dissolve the prerequisites for lasting companionship. (ibid., p. 123)

Pressed by the market, the requirements of family, marriage, parenthood, and partnership are ignored. Just as the traditional form of the 
heterosexual family, based on role distinctions between men and women and aimed at the socialization of children-the family Talcott Parsons referred to in the 1950s (Parsons and Bales 1955)—corresponded to the needs of the industrial and urban society of the mid-twentieth century, the society of singles corresponds to the changed needs of our present-day job market. Nowadays "the labor market demands mobility without regard to personal circumstances" (Beck 1992, p. 116). Especially with the prevalence of telematics and mobile media devices, the current market requires that workers be constantly available, and therefore free from demanding social relationships like those of the traditional family. Beck notes that the final outcome of this process may be a welcome increase in the protection of individual human rights but fears that it will also involve a closing of "the circle of individualization" in which "the designs of independence become the prison bars of loneliness" (ibid., p. 123). The process of individualization has been accompanied by the new models of human relationship favoured by the internet. Wellman, one of the most important scholars writing about the sociology of social media and the web, has called the basic principle of this new communicative situation "individualized networking" or "networked individualism" (Wellman 2001, 2002; Rainie and Wellman 2012).

While it is true that the main reference point of our time is the individual, this individual is not the Promethean self of the Renaissance nor the self-made man of early capitalism, the kind of idealized characters who were the first models of individualism in the modern epoch. The self of our society is a "minimal self," focused only on himself/herself (Lasch 1984). The work of reasoning, making decisions, and planning and executing social change is now performed by enormous organizations and administrative bodies, with individuals becoming less and less central and influential. This can be identified as the process of bureaucratization. Some of the most important scholars of mass society during the 1950s and the 1960s, like Karl Mannheim, Charles Wright Mills, and Robert Nisbet, observed that changes in the structure of the society towards larger dimensions and greater complexity have inevitably issued in more and more bureaucratization, whose formal and inhuman rationality has progressively come to prevail in modern society. The ability of mere individuals to understand the social world has decreased because they do not have the tools to comprehend what is happening around them or the meaning of events and their consequences, let alone the possibility of directing or influencing those events. Facing a technological system that exceeds his/ her possibilities of comprehension and action, the human being shows 
what he/she is: a small being, weak and poor if singularly taken, since many entities can do more and better than he/she does (Donati 2009, p. 117). This transfer of rationality and power from individuals to organizations is strongly fuelled by digital systems and platforms, and it is not by chance that people now think of these systems and platforms, operated by the "custodians of the internet" (Gillespie 2018), as the most powerful entities operating in present-day societies. The big enterprises and administrative bodies, namely the big bureaucracies, have made use of a powerful tool of formal rationality-algorithms - whose inhuman, hidden rationality can decide the fate of enterprises, people, and financial arrangements without having to explain or be accountable to anyone.

The third important structural process operating in contemporary societies is globalization. From an economic standpoint, globalization means the intertwining of world economies and international markets, resulting in the rapid movement of products, capital, and jobs. Enterprises take on worldwide scope without regard for regional and national borders. From a legal and political point of view, the most significant aspect of globalization is the peripheralization of the nation-state, that is, the simultaneous rapid growth of supranational institutions and the waning power and control of the nation-state over economic and financial affairs. Another effect of globalization is the growth in the geographical extension, interconnection, and speed of information and communications technologies. Manuel Castells identifies globalization as "the rise of the network society," characterized by the binomial of connected versus not connected (Castells 1996). This new binomial redefines the meaning of the concepts of identity, belonging, inclusion, sovereignty, and citizenship. The increasing interdependence among global systems implies a dark side involving previously unimagined threats: environmental disasters with a global impact like the Chernobyl accident and the British Petroleum oil spill off the US coast in 2010; the rapid, global spread of diseases like SARS, avian influenza, mad cow disease, and COVID-19; and the growth of illegal networks engaged in drug dealing, money laundering, the weapons trade, and international terrorism. Osterhammel and Petersson have observed that globalization is not an autonomously operating process or an unstoppable historical phenomenon because macroscopic events are always the result of individual and collective activity — the work of globalization involves many different actors with diverse visions and strategies (Osterhammel and Petersson 2009, p. 151). Sometimes, these actions have unintended global side effects. "We must remember that much of what appears in retrospect to have been the logical consequence of a world growing smaller was also 
due to unintended side effects of behavior that definitely has no global aims" (ibid., p. 152). However much that may be the case, globalization is felt by individuals to be a fated and often hostile process led by powers beyond their control, including the impersonal laws of the market, Wall Street tycoons, bureaucrats in Brussels and Washington D.C., Hollywood corporations, and the masters of the internet. The fact that globalization sweeps away identities, local economic systems, traditions, lifestyles, and social relationships has caused widespread bewilderment.

The structural processes we have summarized influence individuals' ways of thinking, feeling, and acting towards their increased reliance on emotion and personal belief, a tendency that is part of the definition of the concept of post-truth. However, our discussion in this book will chiefly focus on reconstructing the historical and theoretical roots of the communicative and cultural processes that were the basis of the intellectual parable told in the second half of the nineteenth century, a parable that resulted in some unexpected, problematic consequences and led more or less directly to the present-day phenomenon of post-truth.

The discussion in our book will unfold in four stages:

The second chapter ('Post-Truth in Practice') focuses on the development of the manipulative practices that have defined the contemporary era from World War I to the present. We will attempt, albeit in a necessarily simplified manner, to provide an original contribution to a critical reconstruction of the picture of what happened and is currently happening in the world of communication.

In the third chapter ('Post-Truth in Theory'), we'll analyse two notable cultural processes that characterized the twentieth century: first, the marked development of the analysis and understanding of human motives, behaviour, social dynamics, and collective phenomena achieved by the psychosocial sciences; and second, the profound critical redefinition of the concepts of 'truth' and 'reality' that took place in the fields of philosophy, psychology, sociology, communication, and journalism. This chapter is intended to offer a multidisciplinary picture of the soil in which the tree of post-truth took root, which in our view has not yet been provided by the numerous essays and commentaries analysing the OED's decision to highlight the term.

The fourth chapter ('The Backlash and Side Effects') will illuminate the consequences generated, voluntarily or involuntarily, by the transformation of the conceptions of truth and reality, which run contrary to the expectations, often so full of hope and good intentions, that accompanied 
this transformation. The sudden arrival in the media and political worlds of new figures who unexpectedly exploited the persuasive power of new media; the unprecedented disruption of communicative hierarchies by the way the internet allows for anyone to become a broadcaster, producer, opinion leader, or influencer; and the risks attendant to the increase in self-referential phenomena on the web, in which communication takes place primarily in homogenous spaces and does not encourage openness to diversity of opinion, are among the most significant of these consequences.

The final chapter 'The Future of Post-Truth: Defences, Defended, and Defenceless' asks who is best equipped to defend himself/herself from the negative effects of post-truth and fake news. We will analyse some of the strategies and proposals that have been advanced to resist the growing threat that post-truth poses to global communications and propose an original, critical solution.

\section{Note}

1. The term 'post-truth' was first used by scholars and journalists in the 1990s (Tesich 1992; Keyes 2004), but it would be years before it would become an established term in either the journalistic or popular lexicon. The expression 'fake news' can be traced back in print to the end of the nineteenth century and perhaps earlier (cf. Merriam-Webster, The Real Story of 'Fake News,' https://www.merriam-webster.com/words-at-play/the-real-story-offake-news).

\section{REFERENCES}

Bateson, G. (1972). Steps to an Ecology of Mind. Collected Essays in Anthropology, Psychiatry, Evolution and Epistemology. London: Jason Aronson Inc.

Beck, U. (1992). Risk Society: Towards a New Modernity. London: Sage.

Bramson, L. (1961). The Political Context of Sociology. Princeton: Princeton University Press.

Castells, M. (1996). The Rise of the Network Society. Oxford: Blackwell.

Darnton, R. (2017). The True History of Fake News. New York Review of Books. Retrieved from http://www.nybooks.com/daily/2017/02/13/the-truehistory-of-fake-news/.

Donati, P. (2009). La società dell'umano. Genova-Milano: Marietti.

Gili, G. (2001). Il problema della manipolazione: peccato originale dei media? Milano: FrancoAngeli. 
Gillespie, T. (2018). Custodians of the Internet: Platforms, Content Moderation, and the Hidden Decisions That Shape Social Media. New Haven and London: Yale University Press.

Giner, S. (1976). Mass Society. London: Martin Robertson.

Keyes, R. (2004). The Post-Truth Era: Dishonesty and Deception in Contemporary Life. New York: St. Martin's Press.

Lasch, C. (1984). The Minimal Self. Psychic Survival in Troubled Times. New York: Norton.

Lefebvre, G. (1932). La grande peur de 1789. Paris: Armand Colin.

Mannheim, K. (1940). Man and Society in an Age of Reconstruction. New York: Harcourt, Brace \& World.

Margalit, A. (2017). On Betrayal. Cambridge, MA: Harvard University Press.

Osterhammel, J., \& Petersson, N. P. (2009). Globalization: A Short History. Princeton: Princeton University Press.

Parsons, T., \& Bales, R. F. (1955). Family, Socialization and Interaction Process. New York: The Free Press.

Rainie, L., \& Wellman, B. (2012). Networked: The New Social Operating System. Cambridge, MA: MIT Press.

Riva, G. (2018). Fake News. Vivere e sopravvivere in un mondo post-perità. Bologna: Il Mulino.

Tesich, S. (1992, January 6-13). A Government of Lies. The Nation.

Wellman, B. (2001). Physical Place and Cyber Place: The Rise of Personalized Networking. International Journal of Urban and Regional Research, 25(2), 227-252.

Wellman, B. (2002). Little Boxes, Glocalization, and Networked Individualism. In M. Tanabe, P. Van den Besselaar, \& T. Ishida (Eds.), Digital Cities II: Computational and Sociological Approaches (pp. 10-25). New York: Springer. 